УДК 625

\title{
ФОРМУВАННЯ СТРАТЕГІЇ ЦІНОУТВОРЕННЯ \\ ПІДПРИЄМСТВ ДОРОЖНЬОГО ГОСПОДАРСТВА НА ОСНОВІ ВАРТІСНОГО ПІДХОДУ ДЛЯ ПІДВИЩЕННЯ ЯКОСТІ ТРАНСПОРТНИХ ПОСЛУГ
}

FORMATION OF THE PRICING STRATEGY
OF ROAD ENTERPRISES ON THE BASIS
OF A COST APPROACH TO IMPROVE
THE QUALITY OF TRANSPORT

\author{
Хоменко Інна Олександрівна \\ доктор економічних наук, профресор, \\ Національний університет «Чернігівська політехніка» \\ ORCID: https://orcid.org/0000-0002-0839-4536 \\ Волинець Людмила Миколаївна \\ кандидат економічних наук, доцент, \\ Національний транспортний університет \\ ORCID: https://orcid.org/0000-0002-5064-2349 \\ Бабаченко Лариса Валентинівна \\ кандидат економічних наук, доцент, \\ Національний університет «Чернігівська політехніка» \\ ORCID: https://orcid.org/0000-0002-6312-4700 \\ Khomenko Inna \\ Chernihiv Polytechnic National University \\ Volynets Lyudmila \\ National Transport University \\ Babachenko Larysa \\ Chernihiv Polytechnic National University
}

\begin{abstract}
Стаття присвячена актуальним питанням ціноутворення підприємств дорожнього господарства на основі вартісного підходу. Визначено основні нормативні документи, якими керуються при визначенні вартості матеріально-технічних ресурсів. Запропоновано заходи запровадження нової стратегії ціноутворення підприємств дорожнього господарства на основі вартісного підходу для підвищення якості транспортних послуг. Проаналізовано вплив окремих витрат на загальну вартість будівництва. Розглянуто порядок визначення вартості виконаних робіт із заготівлі матеріальних ресурсів для зимового утримання. Розкрито особливості визначення вартості зворотніх матеріалів на всіх етапах інвестиційного процесу. Охарактеризовано світовий досвід організації оплати праці. Доведено, що система ціноутворення при визначені вартості дорожніх робіт базується на нормативно-розрахункових показниках і поточних цінах трудових та матеріально-технічних ресурсів.
\end{abstract}

Ключові слова: дорожнє господарство, транспортна інфраструктура, ціноутворення, стратегія, вартісний підхід, будівництво, якість перевезень.

Статья посвящена актуальным вопросам ценообразования предприятий дорожного хозяйства на основе стоимостного подхода. Определены основные нормативные документы, которыми руководствуются при определении стоимости материально-технических ресурсов. Предложены мероприятия введения новой стратегии ценообразования предприятий дорожного хозяйства на основе стоимостного подхода для повышения качества транспортных услуг. Проанализировано влияние отдельных расходов на общую стоимость строительства. Раскрыты особенности определения стоимости обратных материалов на всех этапах инве- 
стиционного процесса. Отмечено, что в составе себестоимости работ необходимо отражать все расходы, относящиеся к статьям калькуляции производственной себестоимости. Охарактеризованы мировой опыт организации оплаты труда. Доказано, что система ценообразования при определении стоимости дорожных работ базируется на нормативно-расчетных показателях и текущих ценах трудовых и материально-технических ресурсов.

Ключевые слова: автомобильные дороги, транспортная инфраструктура, экономическое оценивание, программа, строительство, качество перевозок.

The article is devoted to topical issues of pricing of road management enterprises on basis of the cost approach. It proved that the normative need for material resources per unit of measurement by types of work accepted on basis of resource element estimates, and the normative need for the volume of work calculated on basis of the volume of work provided by drawings and project specifications. The basic normative documents are guide at definition of cost of material and technical resources defined. Measures to introduce a new pricing strategy for road management enterprises based on a cost approach to improve the quality of transport services proposed. The impact of individual costs on the total cost of construction analyzed. The procedure for determining the cost of work performed on the procurement of material resources for winter maintenance considered. The peculiarities of determining the cost of return materials at all stages of the investment process revealed. It noted that the cost of works must reflect all costs related to the list and composition of items for calculating the production cost of products (works, services). The world experience of wage organization characterized, which distinguishes three main models - American, Japanese and Western European. In foreign practice, individual and collective systems of remuneration and incentives are widely used. The amount of the estimated salary in Ukraine, which taken into account when compiling the investor's estimate documentation (at the stage of project documentation development), is determined by the customer (investor) as part of the initial design data for normal construction conditions. It proved that in accordance with national and industry standards, the pricing system in determining the cost of road works based on regulatory and calculation indicators and current prices of labor and material resources. The proposed pricing strategy based on the cost approach will provide a comprehensive definition of the cost of material and technical resources at all stages of the investment process to improve the quality of transport services.

Keywords: road management, transport infrastructure, pricing, strategy, cost approach, construction, quality of transportation.

Постановка проблеми. Для поліпшення якості транспортних послуг і доріг необхідно змінити механізм ціноутворення в будівництві. Нормативна потреба в матеріальних ресурсах на одиницю виміру за видами робіт приймається на підставі ресурсних елементних кошторисних норм, а нормативна потреба на обсяг робіт розраховується на підставі обсягів робіт, передбачених кресленнями та специфрікаціями проекту. Основні нормативні документів, якими керуються при визначенні вартості матеріально-технічних ресурсів, враховуючи вид дорожніх робіт: 1. При виконанні робіт 3 нового будівництва та реконструкції використовують ДСТУ-Н Б Д.1.1-2:2013 відповідно до якого визначається структура і норми витрат на матеріальні ресурси, а також необхідність обґрунтування ціни на основі проведеного аналізу цін на матеріальні ресурси. 2. При виконанні робіт з капітального ремонту використовують СОУ 42.137641918-050:2018, який установлює основні правила і терміни, а також порядок визначення вартості матеріальних ресурсів для капітального ремонту автомобільних доріг загального користування мостів та інших транспортних споруд та СОУ 42.1-37641918-035:2018 відповідно до якого визначається структура і норми витрат на матеріальні ресурси. 3. При виконанні робіт з експлуатаційного утримання використовують СОУ 42.1-37641918-085:2018, який установлює основні правила і терміни, а також порядок визначення вартості матеріальних ресурсів для робіт 3 поточного ремонту та експлуатаційного утримання автомобільних доріг загального користування мостів та інших транспортних споруд та СОУ 42.1-37641918-071:2018 відповідно до якого визначається структура і норми витрат на матеріальні ресурси. Інвестиційний процес включає в себе три стадії: від розробки та затвердження проєктної документації на виконання дорожніх робіт до завершальної стадії прийняття завершеного проєкту та взаєморозрахунків за виконані роботи [1-5].

Аналіз останніх досліджень та публікацій. Теоретичні та методологічні основи формування та використання фрінансових ресурсів підприємствами дорожнього господарства висвітлювали у свої працях А.В. Базилюк, А.О. Безуглий, М.М. Бурмака, Т.В. Деділова, В.В. Концева, І.А. Проценко, І.П. Садловська, та ряду інших науковців, при цьому питання, пов'язані із ціноутворенням, потребують подальшого поглибленого дослідження.

Виділення невирішених раніше частин загальної проблеми. Подальшого дослідження потребує проблема фрормування стра- 
тегії ціноутворення підприємств дорожнього господарства на основі вартісного підходу для підвищення якості транспортних послуг. На сьогодні дорожні мережі не відповідають вимогам на 97\%, тому потреба в будівництві доріг є доволі не вирішеною і суттєво впливає на якість перевезень.

Формулювання цілей дослідження. Метою дослідження є розробка стратегії ціноутворення підприємств дорожнього господарства на основі вартісного підходу.

Виклад основного матеріалу дослідження. Для запровадження нової стратегії ціноутворення підприємств дорожнього господарства на основі вартісного підходу для підвищення якості транспортних послуг необхідно встановити процедуру збору та аналізу інсрормації щодо вартості матеріальних ресурсів проектантами, замовниками, підрядниками. При проведенні такого аналізу мають враховуватися вимоги щодо якості матеріалів, виробів та конструкцій, строків, об'ємів та умов їх постачання тощо. Також потрібно удосконалити процес моніторингу цін на дорожньо-будівельні матеріали з урахуванням транспортної складової залежно від місця розташування об'єкта. Закупівлю матеріальних ресурсів потрібно здійснювати відповідно до Закону України «Про публічні закупівлі» через систему ProZorro. При цьому підрядник, який $€$ переможцем тендеру, не повинен надавати підтверджуючі документи щодо вартості матеріально-технічних ресурсів, а зобов'язаний якісно виконати весь обсяг робіт та за вартістю, зазначеною у договірній ціні. Необхідно врахувати заготівельноскладські витрати, призначені не лише для покриття витрат будівельних організацій на утримання апарату заготівельних служб (відділи постачання, підрозділи виробничо-технологічної комплектації будівельних організацій тощо) та матеріальних базових складів, а також витрат, пов'язаних з втратами, які важко усуваються, і псуванням матеріалів при їх транспортуванні для матеріалів, які не зберігаються на складах. Доцільно внести зміни у діючі договори підряду на роботи з експлуатаційного утримання із зазначенням того, що замовник бере на себе зобов'язання щодо забезпечення робіт з експлуатаційного утримання із заготівлі матеріальних ресурсів для зимового утримання. В додатковій угоді необхідно зазначити перелік дорожніх матеріалів, конструкцій, виробів; кількість ресурсів; терміни та умови передачі; місце передачі; інші умови. Також у разі відсутності у служб авто- мобільних доріг в областях місць для зберігання таких матеріальних ресурсів, необхідно заключати договори на її зберігання.

Порядок визначення вартості виконаних робіт із заготівлі матеріальних ресурсів для зимового утримання наступні:

- вартість виконаних робіт із заготівлі матеріальних ресурсів для зимового утримання повинна включатися в обсяг виконаних робіт за фрактичною вартістю їх придбання з урахуванням сплаченого податку на додану вартість, та відніматися замовником при оплаті за виконаний обсяг робіт. Вартість таких матеріальних ресурсів як матеріалів поставки замовника, безоплатно переданих підряднику за Актом передачі та використаної при проведенні робіт з експлуатаційного утримання, включається в обсяг виконаних робіт за фрактичною вартістю їх придбання 3 урахуванням сплаченого податку на додану вартість (типова фрорма № КБ-3), але при розрахунках за виконаний обсяг робіт віднімається замовником і не підлягає оплаті. В Акті передачі відображається вартість матеріалів за ціною їх придбання з урахуванням сплаченого ПДВ;

- відповідно, у звіті за фрормою № 1-КБ вартість матеріальних ресурсів як матеріалів поставки замовника включається в обсяг виконаних робіт;

-у випадку, коли підрядник своїм транспортом доставляє на об'єкт матеріали поставки замовника, до Актів приймання виконаних робіт за фрормою № КБ-2в крім фрактичної вартості придбання матеріальних ресурсів (3 урахуванням сплаченого ПДВ) включаються також транспортні, а за необхідності, і складські витрати. При взаєморозрахунках за виконані обсяги робіт ці витрати із загальної вартості робіт не виключаються.

Необхідно зазначити в нормативних документах визначення вартості зворотніх матеріалів на всіх етапах інвестиційного процесу. На етапі складання інвесторської кошторисної документації та ціни пропозиції учасника конкурсних торгів (договірної ціни) вартість матеріальних ресурсів визначається: а) коли неможливо визначити стан матеріальних ресурсів на виході - за поточними відпускними цінами на нові матеріали із застосуванням коефріцієнту зносу 0,5; б) коли встановлено можливий придатний стан матеріальних ресурсів, їх вартість приймається за поточними середніми цінами на аналогічні матеріальні ресурси, що склалися в регіоні на той період часу. На етапі проведення взаєморозрахунків вартість матеріальних ресурсів 
визначається: а) за поточними відпускними цінами на нові матеріальні ресурси скорегованими на коефіцієнт зносу; б) за поточними середніми цінами на аналогічні матеріальні ресурси (при всіх рівних характеристиках), що склалися в регіоні на той момент.

У складі собівартості робіт необхідно відображати всі витрати, що відносяться до переліку і складу статей калькулювання виробничої собівартості продукції (робіт, послуг), незалежно від джерела їх отримання (порядку фрормування їх первісної вартості), в тому числі і вартість безоплатно отриманих матеріальних ресурсів. Адже отримання підприємством благодійної допомоги у вигляді ТМЦ або грошових коштів визнаються доходи. Заміна машин та механізмів повинна здійснюватися 3 урахуванням лише технічного обґрунтування - за аналогічними технічними характеристиками, а обґрунтовані витрати підрядника, спричинені зміною умов виконання робіт, можуть перевищують відповідну нормативно-розрахункову вартість, і не є необхідністю в розробці та затверджені індивідуальних ресурсних елементних кошторисних норм. При розрахунку усереднених показників вартості експлуатації дорожніх машин та механізмів максимально враховувати наявний у підрядних організаціях парк машин та механізмів та з урахуванням оцінки сучасного рівня механізації дорожньої галузі, а також враховувати податки, які пов'язані з використанням (утриманням) машин та механізмів.

На європейських підприємствах підприємці мають повне право самостійно встановлювати методи винагороди працівників, вони розробляють і застосовують будь-які фрорми і системи заробітної плати, види преміальних та інших виплат, використовуючи необов'язкові рекомендації та методичні консультації державних органів і наукових установ. Світовий досвід організації оплати праці виділяє три основні моделі - американську, японську і західноєвропейську. У зарубіжній практиці широко використовується індивідуальна і колективна системи оплати і стимулювання праці. Поряд з цим розрізняють відрядну і погодинну форми оплати праці. Відрядна фрорма передбачає виплати в залежності від кількості та якості виробленої продукції, гарантуючи, при цьому, мінімальну заробітну плату. Визначення відрядного заробітку передбачає формування норм виробітку на основі вивчення рухів, дій працівника і визначення часу їх виконання, і встановлення на цій основі відрядної розцінки за одиницю продукції. В результаті встановлюється основна заробітна плата, яка розраховується виходячи з норми вироблення і ставки заробітної плати з урахуванням їх виконання. У розрахунках застосовуються фріксовані, що збільшуються або зменшуються розміри ставок [6-9].

Розмір кошторисної заробітної плати в Україні, який враховується при складанні інвесторської кошторисної документації (на стадії розроблення проектної документації), визначається замовником (інвестором) у складі вихідних даних на проектування для звичайних умов будівництва за розрядом складності робіт 3,8, але не нижче ніж середньомісячна заробітна плата у будівництві (у розрахунку на одного штатного працівника) за попередній звітний рік, що оприлюднюється центральним органом виконавчої влади в галузі статистики, збільшена на прогнозний індекс споживчих цін на поточний рік (у середньому до попереднього року), який є складовою основних прогнозних макропоказників економічного і соціального розвитку України, що схвалюються Кабінетом Міністрів України. Величина, нижче якої не може бути розмір кошторисної заробітної плати, визначається 3 використанням даних щодо середньомісячної заробітної плати у будівництві за попередній звітний рік та прогнозного індексу споживчих цін на поточний рік [10-11]. Відповідно до вищенаведених національних та галузевих стандартів система ціноутворення в будівництві (у тому числі при визначені вартості дорожніх робіт) базується на нормативнорозрахункових показниках і поточних цінах трудових та матеріально-технічних ресурсів. А тому заробітна плата при проведенні взаєморозрахунків (складанні форми КБ-2В «Акт приймання виконаних будівельних робіт») визначається на підставі нормативно-розрахункових трудовитрат, що визначаються 3 використанням кошторисних нормативів і рекомендованої Мінрегіоном та Укравтодором вартості людино-години. Враховуючи це, може мати місце фракт розбіжностей між фактичними витратами на заробітну плату працівників, підтверджених первинними бухгалтерськими документами, та нормативною кошторисною заробітною платою, передбаченою формою КБ-2в. Необхідно підвищити розмір тарифрної ставки робітника 1 розряду на рівні 240 \% від прожиткового мінімуму для працездатних осіб у розрахунку на місяць. Доцільно врахувати в прогнозний індекс споживчих цін наступних років, адже передбачається збільшення середньомісячної заробітної плата у будівництві (у розрахунку на 
одного штатного працівника) на прогнозний індекс споживчих цін лише на поточний рік. Також пропонуємо внести відповідні зміни як в тендерне законодавство, так і в кошториснонормативну базу України щодо обов'язкового висвітлення учасниками тендерних закупівель фрактично виплаченої заробітної плати за минулий період на підставі подання Звіту із праці за фрормою № 1-ПВ (місячна) або № 1-ПВ (квартальна).

Висновки. Розроблена стратегія ціноутворення в частині визначення вартості трудових ресурсів повинна створити належну систему стимулювання та мотивації праці, яка б ураховувала специсріку діяльності у дорожньому господарстві. Таким чином, замовник з урахуванням прогнозного рівня інфрляції зможе вийти на орієнтовний рівень заробітної плати підрядника. Підрядник фрормує очікувану вар- тість закупівлі дорожньо-будівельних матеріалів на підставі власних методичних підходів щодо моніторингу цін, наприклад аналізуючи ціни в своєму та сусідніх регіонах з урахуванням можливого прогнозного рівня інсрляції до моменту закупівлі та відповідно до вимог діючих нормативних документів. Отже, вартісний підхід вимагає обґрунтування кожної складової кошторису.

Запропонована стратегія ціноутворення на основі вартісного підходу забезпечить комплексне визначення витрат матеріальних та технічних ресурсів на всіх стадіях інвестиційного процесу для підвищення якості транспортних послуг, що надаються. Дана стратегія ціноутворення сприятиме уникненню проблем і помилок при визначенні вартості дорожніх робіт та удосконаленню діючих методичних документів.

\section{СПИСОК ВИКОРИСТАНИХ ДЖЕРЕЛ:}

1. Кичко I.І., Парубець О.М. Напрями використання технологій HR-менеджменту у транспортному секторі України. Проблеми і перспективи економіки та управління. 2020. № 4(24). С. 34-42.

2. Кичко І., Борисенко Л., Левченко М. Умови фрормування трудового потенціалу підприємств морського транспорту та фрактори його реалізації. Проблеми і перспективи економіки та управління. 2019. № 3(19). C. 126-135.

3. Про затвердження Методики визначення обсягу фінансування будівництва, реконструкції, ремонту та утримання автомобільних доріг та нормативів витрат, пов'язаних з утриманням автомобільних доріг : наказ Міністерства інсрраструктури України, Міністерства фрінансів України від 21.09.2012 № 573/1019. URL: https://zakon.rada.gov.ua/laws/show/z1734-12

4. Безуглий А.О., Бібик Ю.М., Гресько І.Л., Бельська О.Л. Особливості інформаційно-довідкової системи щодо побудованих та запроектованих об'єктів-аналогів при оцінці вартості дорожніх робіт. Дороги і мости. 2021. Вип. 23. С. 8-19.

5. Безуглий А.О., Бібик Ю.М., Гресько І.Л., Бельська О.Л., Концева В.В. Фінансова спроможність дорожніх підприємств - як один із критеріїв для участі у процедурі закупівлі. Дороги і мости. 2021. Вип. 24. С. 8-19.

6. МРД.1.2-37641918-915:2020 Методичні рекомендації з визначення фінансової спроможності дорожніх підприємств. Київ, 2020. 18 с.

7. ДСТУ Б Д.1.1-7:2013 Правила визначення вартості проектно-вишукувальних робіт та експертизи проектної документації на будівництво. Київ, 2014. 83 с.

8. Хоменко І.О., Волинець Л.М., Лисенко Г.О. Особливості державно-приватного партнерства як механізм реалізації нової регіональної політики для функціонування та розвитку дорожнього господарства. Науковий вісник Полісся. 2020. № 2(21). С. 73-82.

9. Хоменко І.О., Волинець Л.М., Лисенко О.В. Економічне оцінювання розвитку доріг та транспортної інфрраструктури в контексті підвищення якості перевезень. Економіка та суспільство. 2021. № 30. URL: https://economyandsociety.in.ua/index.php/journal/article/view/661/635

10. Бабаченко Л.В., Ковшун Х.О., Портна Ю.О. Особливості управління конкурентоспроможністю підприємства. Проблеми і перспективи економіки та управління. 2019. № 3(19). С. 33-40.

11. Бабаченко Л.В., Москаленко В.А. Маркетингове ціноутворення в аграрному секторі. Стратегічні напрямки і пріоритети трансформаційного поступу України : монографрія / за заг. ред. М.М. Забаштанського. 2019. С. 278-302.

12. МР Д.2.4-37641918-911:2020 Методичні рекомендації з визначення прогнозних обсягів робіт з експлуатаційного утримання автомобільних доріг загального користування при реалізації довгострокових договорів (контрактів). Київ, 2020 (Інорормація та документація). 


\section{REFERENCES:}

1. Kychko I.I., Parubets O.M. (2020) Napriamy vykorystannia tekhnolohii HR-menedzhmentu u transportnomu sektori Ukrainy. [Areas of use of HR management technologies in the transport sector of Ukraine]. Problems and prospects of economics and management, no. 4(24), pp. 34-42.

2. Kychko I., Borysenko L., Levchenko M. (2019) Umovy formuvannia trudovoho potentsialu pidpryiemstv morskoho transportu ta faktory yoho realizatsii [Conditions for the formation of labor potential of maritime transport enterprises and factors of its implementation]. Problems and prospects of economics and management, no. 3(19), pp. $126-135$.

3. Pro zatverdzhennia Metodyky vyznachennia obsiahu finansuvannia budivnytstva, rekonstruktsii, remontu ta utrymannia avtomobilnykh dorih ta normatyviv vytrat, poviazanykh z utrymanniam avtomobilnykh dorih: nakaz Ministerstva infrastruktury Ukrainy, Ministerstva finansiv Ukrainy vid 21.09.2012 № 573/1019 [On approval of the Methodology for determining the amount of financing for construction, reconstruction, repair and maintenance of roads and standards of costs associated with the maintenance of roads: Order of the Ministry of Infrastructure of Ukraine, Ministry of Finance of Ukraine from 21.09.2012 № 573 / 1019]. Retrieved from: https://zakon.rada.gov.ua/laws/show/ z1734-12

4. Bezuhlyi A.O., Bibyk Yu.M., Hresko I.L., Belska O.L. (2021) Osoblyvosti informatsiino-dovidkovoi systemy shchodo pobudovanykh ta zaproektovanykh obiektiv-analohiv pry otsintsi vartosti dorozhnikh robit [Features of the information and reference system for the constructed and designed analogous objects when estimating the cost of road works]. Roads and bridges, vol. 23, pp. 8-19.

5. Bezuhlyi A.O., Bibyk Yu.M., Hresko I.L., Belska O.L., Kontseva V.V. (2021) Finansova spromozhnist dorozhnikh pidpryiemstv - yak odyn iz kryteriiv dlia uchasti u protseduri zakupivli [Financial capacity of road enterprises is one of the criteria for participation in the procurement procedure]. Roads and bridges, vol. 24, pp. 8-19.

6. MRD.1.2-37641918-915:2020 Metodychni rekomendatsii $z$ vyznachennia finansovoi spromozhnosti dorozhnikh pidpryiemstv [Methodical recommendations for determining the financial capacity of road enterprises]. Kyiv, 2020. 18 p.

7. DSTU B D.1.1-7:2013 Pravyla vyznachennia vartosti proektno-vyshukuvalnykh robit ta ekspertyzy proektnoi dokumentatsii na budivnytstvo [Rules for determining the cost of design and survey work and examination of design documentation for construction]. Kyiv, 2014. 83 p.

8. Khomenko I.O., Volynets L.M., Lysenko H.O. (2020) Osoblyvosti derzhavno-pryvatnoho partnerstva yak mekhanizm realizatsii novoi rehionalnoi polityky dlia funktsionuvannia ta rozvytku dorozhnoho hospodarstva [Features of public-private partnership as a mechanism for implementing a new regional policy for the functioning and development of the road sector]. Scientific Bulletin of Polissya, no. 2(21), pp. 73-82.

9. Khomenko I.O, Volynets L.M, Lysenko O.V. (2021) Ekonomichne otsiniuvannia rozvytku dorih ta transportnoi infrastruktury v konteksti pidvyshchennia yakosti perevezen [Economic assessment of the development of roads and transport infrastructure in the context of improving the quality of transport]. Economy and society, no. 30. Retrieved from: https://economyandsociety.in.ua/index.php/journal/article/view/661/635

10. Babachenko L.V., Kovshun Kh.O., Portna Yu.O. (2019) Osoblyvosti upravlinnia konkurentospromozhnistiu pidpryiemstva [Features of enterprise competitiveness management]. Problems and prospects of economics and management, no. 3(19), pp. 33-40.

11. Babachenko L.V., Moskalenko V.A. (2019) Marketynhove tsinoutvorennia v ahrarnomu sektori [Marketing pricing in the agricultural sector]. Strategic directions and priorities of transformational progress of Ukraine: a monograph on the general / ed. M.M. Zabashtansky. Pp. 278-302.

12. MR D.2.4-37641918-911:2020 Metodychni rekomendatsii z vyznachennia prohnoznykh obsiahiv robit z ekspluatatsiinoho utrymannia avtomobilnykh dorih zahalnoho korystuvannia pry realizatsii dovhostrokovykh dohovoriv (kontraktiv) [Methodical recommendations for determining the estimated volume of work on the maintenance of public roads in the implementation of long-term agreements (contracts)]. Kyiv, 2020 (Information and documentation). 